\title{
Liberdade e igualdade
}

\section{CÉLIA GALVÃO QUIRINO}

A Liberdade e a Igualdade são temas fundamentais da Ciência Política. São tratados desde a antigüidade pela filosofia política sem que os termos apresentem, no entanto, o mesmo sentido, a mesma significação. Se hoje falamos de Liberdade, esta idéia não representa para nós o mesmo que representaria para os gregos da época de Péricles, para os filósofos da Ilustração, ou mesmo para um cidadão chinês de nossos dias. Da mesma forma, a idéia de Igualdade assume significações diferentes nas diferentes situações sócio-históricas. Se os temas são retomados e rediscutidos, a história impede que eles o sejam da mesma maneira. Assim sendo, poderíamos dizer que, a cada compreensão da idéia de Liberdade, deveríamos perguntar, em primeiro lugar, para quem e, em seguida, para que esta Liberdade. É como se, em cada uma de suas manifestaçбos, a idéia de Liberdade fosse pensada por e para algumas pessoas somente. A Liberdade de um príncipe não é a Liberdade de seus súditos, a Liberdade da burguesia não é a da classe operária. A Liberdade não é, portanto, algo genérico; o que é igualmente válido para a Igualdade. Existem Liberdades e Igualdades específicas, às quais os diferentes liberalismos e igualitarismos atribuem valores diferentes.

Os séculos XVII e XVIII poderiam ser encarados como o momento em que a filosofia política passa a discutir o problema da Liberdade e da Igualdade como inseparáveis, sobre o fundo da condição natural do Homem. É sobretudo com o jusnaturalismo moderno que a compreensão da sociedade civil e.da política passa, necessariamente, por uma explicação da natureza humana agora referida a um Estado de Natureza e não mais à Ordem Divina. Para os filósofos da Escola do Direito Natural, o Estado de Natureza é sempre um estado de independência: assim, estes pensadores imaginam o Estado de Natureza a partir da existência de homens que nascem livres e iguais. Não nos interessa discutir se o Estado de Natureza imaginado nesse período é bom ou mau, se é um estado de guerra ou de paz total, se é realidade que exis- 
tiu, existe ou existirá, ou se trata de simples abstração; o que importa é que ele contém sempre a mesma condição natural de Liberdade e Igualdade, inerente a todos os seres humanos ao nascer. $\mathrm{O}$ passo seguinte, dado pelos juristas da Escola de Direito Natural (passo, talvez, ainda mais significativo), é a consideração de que, se os homens nascem livres e iguais, a Liberdade e a Igualdade devem ser tratadas como Direitos Naturais.

Uma vez estabelecidos um Estado de Natureza e os Direitos Naturais dos homens, impōe-se aos pensadores políticos a explicação do surgimento da Sociedade Civil e do Estado. A questão levantada no Contrato Social, a de que "o homem nasce livre, mas por toda a parte ele se encontra agrilhoado", não foi, certamente, apenas um drama rousseauniano. Sem dúvida, é a partir de questōes semelhantes que se construiu todo o pensamento político do jusnaturalismo.

Uma vez que o Direito Divino do Soberano é contestado, a pergunta que se passa a fazer não é apenas a de quem concede a Soberania e a legitima; é preciso saber, também, por que ela é aceita. Em outras palavras, como é possivel os homens criarem e aceitarem um novo tipo de Dominação, perdendo assim a Liberdade e a Igualdade naturais? A solução proposta pelos Contratualistas é a realização de Convençōes, do Contrato.

A idéia de que o Contrato, realizado entre os homens iguais e livres, é necessária para dar nascimento a uma Sociedade Civil e, an mesmo tempo, tornar legítima a autoridade política e o Estado, passa a ser o tema comum aos pensadores políticos da época. Os Contratualistas vão aí encontrar a explicação, seja para a perda da Liberdade e Igualdade Naturais, seja para sua manutenção em outros moldes. ${ }^{1}$

Deixando de lado os motivos que levam os homens a abandonar o Estado de Natureza ${ }^{2}$, torna-se importante, para a teoria política, o fato de que é o Contrato que resolve o problema do fundamento da autoridade e da origem do Estado. Embora todos os contratualistas partissem de uma concepção de Igualdade e Liberdade entre os homens

(1) No primeiro caso, poderíamos citar Grotius, para quem, embora os poderes soberanos, em sua origem, pertençam ao povo, tais poderes podem ser legitimamente transferidos (através do Contrato) para um Soberano Absoluto. O que suprime tanto a Liberdade quanto a Igualdade. No segundo caso, o melhor exemplo é, sem dúvida, Rousseau, para quem a liberdade e a igualdade naturais são suprimidas, dando nascimento, a partir do Contrato, à Liberdade e à Igualdade Civis.

(2) Entre os vários motivos que levam os homens a abandonar o Estado de Natureza, poderíamos citar, como exemplos extremos, desde a idéia hobbesiana da impossibilidade de sobrevivência no Estado de Natureza por ser este um Estado de Guerra, até as idéias de um Puffendorf ou de um Locke, onde o Estado de Natureza é visto como um estado de paz e o Contrato é justamente pensado como condição necessária para preservar este estado de paz. 
como naturais, o contrato val permitır a justificação da existência do Estado, dos mais autoritários aos mais liberais e mesmo aos mais igualitários.

De qualquer forma, na relação Individuo-Sociedade-Estado, o Contrato possibilitará o aparecimento da figura do Cidadão. Tanto no nível da Teoria como no da própria realidade sócio-política, o cidadão passa a encarnar a idéia de que, tendo o indivíduo nascido livre e igual, ele aceitará como legítima a existência do Estado e da Dominação, pela pura e simples razão de que pactuou livremente e, portanto, é um Cidadão e não mais um súdito. Isto é, as Leis, as Constituições se encarregarão de criar esta figura, explicitando seus direitos e deveres face à sociedade e ao Estado, permitindo, assim, a visão do Cidadão como a de um homem livre e igual aos demais perante a lei. Portanto, a Liberdade e a Igualdade, que apareceriam como naturais num primeiro momento, surgem, agora, como privilégio do cidadão, uma vez que o ser cidadão já é um privilégio na prática, embora, na teoria política, permaneça como condição a que todos têm acesso.

Dois problemas apresentam-se imediatamente, tanto no nível do concreto quanto no nivel da discıssão teórica: quais são os limites da liberdade individual, social, política, e por onde deve passar o corte da Igualdade? Voltamos, assim, à nossa questão inicial: Liberdade para que e para quem?

O nascimento do cidadão passa, pois, necessariamente, por estas considerações. No nível das relaçōes econômico-sociais, a idéia de que as relaçôes de trabalho resultam de um contrato livre permite, no século XVIII, a visão de individuos livres contratandó-se para realizar a produção e a distribuição. No nível do político, a participação livre é dada, fundamentalmente, pela possibilidade de escolher e ser escolhido. A escolha e seu segredo garantem a idéia de que votar é um ato de liberdade.

Nos séculos XVII e XVIII, a cidadania aparece como algo genérico. Teoricamente, de Hobbes a Rousseau, tem-se a impressão de que a imagem do Cidadão é algo abstrato, embora a condição de Cidadão seja necessária para os homens existirem em sociedade. Se todos os homens são iguais, todos seriam ou poderiam ser Cidadãos. A Liberdade e a Igualdade são, então, preservadas na figura do Cidadão.

As revoluções dos séculos XVII e XVIII se encarregam de formalizar e concretizar a existência do Cidađão. ${ }^{3}$ A Declaração da Independência Americana, a Declaração dos Direitos Humanos, as Constituiçōes revolucionárias, ou melhor, as Constituiçôes da "Liberal-Democracia",

(3) Tocqueville afirmava que a Revolução Francesa havia tido um caráter europeu-universal, na medida em que não se falava apenas no cidadão francês, mas no cidadão em geral (O. C., Tomo II, vol. 1, p. 89). 
em geral, afirmarão sempre que os cidadãos são livres e iguais, embora a prática constitucional, expressa na legislação ordinária, mostre o contrário. Se, formalmente, o Contrato político encontra sua melhor expressão nestas Constituiçðes, concretamente a cidadania é conquistada através das lutas pelo sufrágio universal, pelas "vantagens sociais", etc. Estas lutas e as revoluçōes em geral são a maneira pela qual - à proposição formal: todos os cidadãos são iguais e livres - se dá a resposta concreta à questão fundamental: para quem a Liberdade? Em outras palavras, são tentativas de ampliar socialmente a categoria de Cidadão, procurando aumentar, asim, a faixa da Igualdade.

Mas a propriedade, desde o início, determina quem pertence a esta faixa de iguais. Esta é a primeira forma que assume a resposta à questão: para quem a Liberdade? Para os pensadores políticos dos séculos XVII e XVIII, a propriedade surge ora como necessária para preservar a união da Liberdade e da Igualdade, ora como uma cunha que compromete essa bela união. No segundo caso, é a propriedade que vai permitir que uma negue a existência da outra, impossibilitando a realização da união como universal, e desenvolvendo a contradição básica do pensamento liberal clássico.

Para a filosofia do Direito Natural, no Estado de Natureza, nas suas mais diferentes concepçбes, tudo pertence a todos. Locke será o primeiro a estabelecer, na relação trabalho-natureza, o direito à propriedade. É o trabalho de cada um sobre a natureza que lhe dá o direito de posse. ${ }^{4}$ Por outro lado, explica muito bem Freyer, a propriedade já não mais incide sobre os homens, mas sobre as coisas. ${ }^{5}$

O conceito de propriedade se limitava, assim, à apropriação da natureza, enquanto necessária à própria existência. O que passa a ser discutido, então, é o direito ou não ao excedente.

(4) "Embora a água que corre na fonte seja de todos, quem poderá duvidar que na bilha está somente a que pertence a quem a recolheu? Pelo trabalho tirou-a das mãos da natureza onde era comum e pertencia igualmente a todos e de tal forma se apropriou para si mesmo. Assim esta lei da razão torna o veado propriedade do índio que o matou; permite-se que pertençam os bens àquele que dedicou o próprio trabalho". (LOCKE, John, - Segundo Tratado sobre o Governo, IBRASA, 1963, cap. V, itens 29, 30). Para Rousseau, já a propriedade aparece como fundadora da Sociedade Civil e, como tal, responsável pelo estabelecimento da desigualdade civil entre os homens: "O verdadeiro fundador da sociedade civil foi o primeiro que, tendo cercado um terreno, lembrou-se de dizer 'isto é meu' e encontrou pessoas suficientemente simples para acreditá-lo" (ROUSSEAU, J. J., - Discurso sobre a origem e os fundamentos da desigualdade entre os homens, ed. Abril, 1973, p. 263).

(5) Embora a escravidão e, em muitos lugares ainda, a servidão continuassem existindo, o estudo de Freyer tenta explicar como, neste período, o sentido e importância da propriedade já haviam se deslocado do ser humano para as coisas (FREYER, Hans, - Sociologia, Ciência da Realidade). 
Lembremos que, no caso de Locke, não só a propriedade é uma necessidade, como a sua preservação constitui o fim principal da Sociedade Civil, ${ }^{6}$ ao passo que, para Rousseau, a propriedade, embora necessária para a existência, já era um elemento perturbador na discussão sobre as condiçðes da manutenção da Liberdade e da Igualdade. Perturbação tão bem resolvida em Rousseau pelo próprio Contrato Social e, sobretudo, pela soberania da Vontade Geral.

Mas, se Rousseau já havia detectado este elemento perturbador, nascido no momento mesmo em que sua existência é reconhecida, é somente no século XIX que a questão da contradição entre essas categorias começa a aparecer para os pensadores políticos.

O século XIX recupera criticamente todos esses temas. O homem natural não existe: o que existe são homens desiguais na propriedade e na liberdade. A visão econômica, tendo se apoderado do conceito de propriedade, já havia, desde o século XVIII, penetrado a visão política, numa superposição de dimensões diferentes que reencontramos mesmo nos textos de hoje. A propriedade, enquanto posse de bens materiais, a riqueza ou, enfim, o capital, iria se encarregar de estabelecer as diferenças, tanto no nível social como no político. As liberdades políticas serão para os cidadãos e os cidadãos serão poucos.

Mas o legado do século XVIII ao XIX não será a mera recuperação de temas teóricos. Se, por um lado, a filosofia política continuava a se debater em torno da contradição Liberdade-Igualdade-Propriedade, por outro, concretamente, a Revolução Francesa havia sido a grande experiência trágica, onde a tentativa de implantação da Igualdade, em nome da Liberdade, acabou por assegurar uma nova desigualdade, e apenas deixou formalizada, nas Declarações e nas Constituições, a Liberdade de alguns poucos.

A crença em novas revoluções salvadoras, que permitissem implantar o reino da Igualdade e da Liberdade, continua existindo, é claro, mas 1848 será mais uma demonstração da tragédia revolucionária. Não apenas 48 repetiu comicamente 89 , como afirmava Marx no Dezoito Brumário de Luiz Bonaparte, mas ambas desaguaram em Impérios onde a Igualdade e, sobretudo, a Liberdade seriam ainda mais violentadas.

O século XIX aprende rapidamente que as classes sociais existem, e que, se o trabalho pode levar à acumulação e à riqueza (como já pregava a doutrina calvinista), esta pode levar à cidadania. Mas descobre também que, se a propriedade é necessária e só o trabalho a produz, é preciso, igualmente, possuir o trabalho de outrem. Esta relação necessária (riqueza de uns, pobreza de outros) se desenvolve à medida

(6) Não podemos deixar de lembrar que o conceito de propriedade para John Locke significa a propriedade de si, da sua liberdade e seus bens (LOCKE, John, op. cit., itens $85,123,124)$. 
que cresce o processo de industrialização. Mais ainda, a concentração de ricos e pobres, dentro de um perímetro urbano, torna impossível a ocultação da desigualdade. Os grandes centros urbanos industriais não conseguirão (pelo menos até a primeira metade do século) esconder, nem afastar, a miséria da vida cotidiana de homens, mulheres e crianças, pertencentes ao proletariado, no sentido mais profundo do termo. ${ }^{7}$

$\mathrm{O}$ fato de que a industrialização havia dividido os países em classes sociais tão desiguais impunha uma solução igualitária ou, pelo menos, conciliatória.

A Revolução Francesa também havia espalhado o mito da Fraternidade. Este mito se tornará necessário para contrabalançar a fenda aberta pela Propriedade no binômio Liberdade-Igualdade. Embora a Fraternidade, no seu contexto revolucionário, tivesse sido a resposta, não apenas aos diferentes interesses individuais ou às diferentes vontades particulares rousseaunianas, mas também à necessidade de incorporar a massa de despossuídos que havia tido um papel tão radicalizador durante a Revolução. Como a Revolução não podia excluir os não-cidadãos (sempre "perigosos"), encontrou-se a idéia de Fraternidade como meio de incorporá-los à Nação. Todavia, é o século XIX que a preserva, desenvolve-a junto com a idéia de Nação e a relaciona, não mais aos diferentes interesses individuais, mas, muito mais adequadamente, aos contraditórios interesses das classes sociais. A essas vontades que se opõem, contrapõe-se o mito de que todos pertencem à mesma pátria e, nesta, são irmãos.

O liberalismo econômico já havia estabelecido que a riqueza do cidadão faria a riqueza da Nação. O pensamento político do século XIX transforma esta proposição, adequando-a à idéia de que as nações devem ser livres, grandes e poderosas para que os individuos-cidadãos

(7) Não é à toa que as grandes Utopias desse período, e suas tentativas de implantação, passavam quase sempre por projetos arquitetônicos. Vejam-se, por exemplo, as construções Owenianas de New Lamarck na Escócia, ou a Harmonia nos Estados Unidos, ou ainda os projetos dos Falanstérios, alguns que, como o "Familistère" em Guise, construído por André Godin, chegaram a ser realizados. Todos estes projetos e construções surgiram como tentativas, viáveis ou não, para solucionar o problema da miséria urbana. Esta miséria que, além de ser visível, abalava as consciências, quando denunciadas pela literatura contemporânea, tal como o fizeram escritores como Victor Hugo, Eugène Sue, Charles Dickens. E, é claro, não podemos deixar de citar as evidentes preocupações dos analistas sociais, ao descrever as condiçôes de vida dos trabalhadores industriais como o fazem Marx, em algumas passagens de $O$ Capital, Engels em $A$ situação da classe trabalha. dora na Inglaterra, ou ainda Tocqueville nos seus relatos de viagem à Inglaterra. Lembraria ainda que, em Paris, a famosa reforma de Haussmann, na época de Napoleão III, sempre apontada como anti-revolucionária, ou melhor, antibarricada, foi, sobretudo, realizada para (segregando as classes sociais no espaço) poupar, aos "puros", "limpos" e "sensíveis" olhares da alta burguesia parisiense, o terrível espetáculo da miséria. 
possam ser livres e, assim, trabalhar pela sua grandeza. ${ }^{3}$ O problema fundamental, todavia, emerge quando se vê que, embora quase todos trabalhem (e, sem dúvida, a grande maioria muito mais do que uns poucos), apenas alguns têm o privilégio da cidadania e, portanto, poucos são livres, mesmo que se aproveitem apenas daquelas liberdades que são formalmente generalizadas nas Constituições e Declarações de Direitos.

A idéia da Nação-Pátria confunde-se, por vezes ambiguamente e, talvez, propositadamente, com a de Estado. Embora a cidadania e, portanto, as liberdades constitucionais valham apenas para os membros do Estado, a Fraternidade deve englobar todos os nacionais.

O pensamento político do século XIX (nas suas várias críticas ao tratamento dado pelo Liberalismo Clássico às questões da Liberdade e da Igualdade) desenvolve-se, portanto, a partir da descoberta de que a Sociedade-Nação traz em si a contradição de interesses de classes, mas também que a Nação pode e precisa ter interesses que sejam de todo o povo.

As explicações passam ora pela necessidade de harmonizar as classes, apelando para o interesse geral nacional e muitas vezes universal, ora pela impossibilidade de se encontrar esta harmonia entre as classes (enquanto classes existirem) e o Estado ou Estados não forem destruidos. Embora a confusão Estado-Nação tenha sido sempre uma constante, parece que o pensamento político do século XIX a acentua, englobando os dois termos num só conceito. ${ }^{9}$

O culto à Nação, a soberania da Nação em lugar da do Rei, introduzidos pela Revolução Francesa, percorrem todas as preocupações políticas do século XIX. Com exceção das idéias anarquistas, talvez nenhuma outra teoria política deixaria de insistir na necessidade de a Nação ser poderosa. Assim, o autoritarismo estatal vê na Pátria Grande a única explicação para a existéncia dos cidadãos; o novo liberalismo, dissociando claramente Estado e Nação, embora seja favorável a Estados fracos e descentralizados, não abandona a idéia de que a Nação precisa ser poderosa; e, finalmente, até mesnio o socialismo de Marx, apesar do seu internacionalismo proletário, tão difundido a partir do Manifesto Comunista, não deixa de defender, em 1848, a necessidade de

(8) Esta codeterminação "Cidadão-Nação" mantém-se viva até nossos dias. Assim como Maquiavel havia estabelecido que, na relação Príncipe-Povo, a existência de um implicava a determinação e o reconhecimento do outro, da mesma forma a própria existência do cidadão - sua liberdade, riqueza e felicidade implicará necessariamente a existência da Nação livre e poderosa, como tão bem souberam estabelecer os americanos, em sua independência, e os franceses, em 89.

(9) Talvez o termo Estado-Nação fosse usado propositadamente, não apenas para diferenciá-lo da Cidade-Estado grega, ou do Estado-Cidade italiano, mas, sobretudo, para denotar as Naçōes que foram capazes de se organizar como Estados Modernos. 
se constituir a nação alemã. ${ }^{10}$

O problema que se coloca, então, para o pensamento político do século XIX, é o de estabelecer diante da tensão Liberdade-Igualdade/Pátria Grande quais liberdades individuais (do Cidadão) não negam a existência de uma Nação poderosa, ou como uma Nação, sendo poderosa, pode permitir que seus cidadãos tenham certas liberdades.

No século XIX, esta relação Nação poderosa-cidadãos livres evoca naturalmente a necessidade do desenvolvimento, do progresso visto como universal, mas também o fato de que cada Nação, para construir sua grandeza, deve ser livre, deve crescer, deve expandir-se, o que se faz necessariamente em detrimento das outras.

A concepção de Progresso, tal como se apresenta no século XIX, está sempre ligada à de Liberdade. O Iluminismo havia desenvolvido a crença de que a razão, o conhecimento, tornavam os homens sábios e, portanto, melhores. No século XIX, o Progresso vai encarnar, não só a idéia de que os homens poderão, desenvolvendo a tecnologia, libertar-se da necessidade do trabalho e da miséria, como também a certeza do crescente aperfeiçoamento do gênero humano; enfim, a idéia de que as Naçōes prosperariam e os homens terminariam, gradualmente ou não, com a luta de classes, dando nascimento a um mundo melhor: o reino da Liberdade e da Igualdade. ${ }^{11}$

Cumpre salientar que, se a necessidade da Nação livre e poderosa leva à libertação e à construção de novas Naçðes, leva também a novas conquistas. Se, por um lado, portanto, assistimos a lutas de independência e à formação de novas Nações (sobretudo nas Américas, onde o exemplo dos Estados Unidos é seguido), por outro, será também o momento de um novo colonialismo expansionista, onde cada Nação européia precisa marcar sua grandeza com novas conquistas, retalhando o continente africano ou dominando os velhos povos asiáticos.

No primeiro caso, a liberdade individual só poderá ser pensada após a libertação da Colônia. A Liberdade Nacional passa a ter prioridade sobre a Liberdade do Indivíduo. Em outras palavras: uma Nação

(10) Marx, em seus artigos na Gazeta Renana, por ocasião da revolução de 48 na Alemanha, defende a necessidade de uma pátria alemã una e indivisível: "Na Alemanha a luta pela centralização, contra um sistema federativo, é a luta entre a civilização moderna e o feudalismo... não pedimos, o que seria utópico, que seja proclamada a priori uma república alemã una e indivisível..." (MARX, K. e ENGELS, F. - La Nouvelle Gazette Rhénanne I, 7 junho 1848).

(11) Na questão que se colocava Marx (Socialismo ou Barbárie?), estava também implícita a idéia de progresso tecnológico como fator para o desenvolvimento do Capitalismo e da futura revolução que daria nascimento à sociedade comunista, visualizada esta como o reino da igualdade e da liberdade. A única oposição a esta crença seria, talvez, a realizada por alguns românticos. É preciso lembrar, todavia, que a discordância romântica não negava o progresso, pois nele
via algo de incontrolável e inevitável. 
que não é livre não pode ser constituída de cidadãos livres. Este é o tipo de discussão que já encontramos em Maquiavel, nos economistas clássicos, em Hobbes e mesmo na sociologia política mais moderna. Na verdade, a pergunta que todos formulam é: o que faz uma Nação ser livre? Uma Nação, para ser livre, deve necessariamente ser poderosa? Uma Nação é poderosa pela sua riqueza, seu complexo militar, seu domínio sobre outras? A tal ponto estes fatores se imbricam, que é difícil dizer o que a faz realmente mais livre, mais independente..$^{12}$

No segundo caso, a manutenção das colônias e a realização de novas conquistas são necessárias para a Nação ser poderosa e livre. Novamente, o poder da Nação e sua liberdade se juntam para caracterizar as condições fundamentais para que o Cidadão seja livre.

Nessa complexa discussão sobre as liberdades do Cidadão e suas relaçбes com a grande Nação, o pensamento político do século XIX define suas abordagens, explorando também a já clássica relação Indivíduo-Sociedade-Estado. As diferentes opções teóricas surgirão e se apresentarão segundo os diferentes esquemas de privilégios que atribuem ao Indivíduo, à Sociedade ou ao Estado, como determinantes da Liberdade ou Igualdade. Parafraseando Maquiavel, a questão a ser proposta será: onde colocaremos a guarda da liberdade - no Indivíduo, na Sociedade ou no Estado? Quem decidirá e estabelecerá a Igualdade ${ }^{13}$

Diríamos que tanto as visðes liberais quanto as socialistas ou as estatistas (chamaremos aqui de estatistas aquelas que privilegiam o Estado como determinante da Liberdade e da Igualdade, tanto individual como social) são as linhas mestras com que se debaterão as teorias políticas até nossos dias.

O Liberalismo, apesar de reconhecer a necessidade da existência do Estado como garantia da lei e da ordem, teme sua força e privilegia sempre as Liberdades dos cidadãos em detrimento da Igualdade dos Indivíduos (a totalidade da sociedade) e do poder do Estado. Todos podem ser livres e iguais desde que sejam cidadãos e desde que não perturbem a grandeza da Nação. Mas, também, o poder do Estado não pode cercear a Liberdade dos cidadãos. E o progresso, um dia, transformará todos em cidadãos.

(12) As análises políticas contemporâneas trabalham justamente esta complexidade do problema, ao caracterizar as Nações mais pobres como dependentes.

(13) A questão levantada por Maquiavel no Livio I, cap. V dos Comentários sobre a primeira década de Tito Livio é: a quem confiar com segurança a guarda da Liberdade, aos aristocratas ou ao povo? Maquiavel não se esquiva das dificuldađ́es da questão: "não se pode determinar com clareza que espécie de homem é mais nociva numa república; a dos que desejam adquirir o que não possuem ou a dos que só querem conservar as vantagens já alcançadas" (Ed. Universidade de Brasília, 1979, p. 33-34). 
O socialismo dirá que a Liberdade só será possível se uma verdadeira igualdade existir. Não apenas a formal, a determinada pela lei, como a dos cidadãos liberais, mas a real, dentro das possibilidades estabelecidas pela Sociedade como um todo e para todos os Individuos. Só uma Sociedade de iguais poderá permitir a existência de liberdades individuais. O Estado, embora ameaçador, poderá ser a força que estabelecerá esta Igualdade e poderá desaparecer quando ele não mais for útil, pois não mais haverá necessidade de obrigar alguém a ser livre. A própria Igualdade, a Sociedade como um todo, e somente ela, será a guardiã da Liberdade. E as revoluções, violentas ou não, permitirão no futuro que todos sejam iguais e livres, tão iguais e tão livres que as próprias diferenças nacionais, como os Estados, poderão desaparecer.

Para outros, porém, somente o Estado forte, poderoso como

a Nação que encarnará, poderá determinar quais são e para quem são as liberdades. Somente ele decidirá do corte de igualdade e somente ele poderá controlar os abusos dos Indivíduos e da Sociedade. Somente o Estado forte, autoritário, poderá realizar a Pátria Grande e Livre, e, portanto, a Liberdade dos seus súditos-cidadãos.

Poderíamos ainda acrescentar que as várias visões, suas variaçð̄es, tendências e combinações possíveis, sempre apresentarão um lado romântico, pouco realista, ou apenas saudoso de um passado não muito distante, ou mesmo pouco interessado em estabelecer ou realizar análises científicas. Assim, há desde proposições onde a impossibilidade do conhecimento da realidade política torna difícil considerá-las como científicas, onde as perspectivas de mudanças são vistas como utópicas, até aquelas que, embora com um tratamento mais cuidadoso do conhecimento da realidade, temem o desenvolvimento da técnica, do progresso que poderá desumanizar os homens, massificando-os.

Mas há sempre, também, a esperança de uma nova ciência do político, que surge com o nascimento de uma ciência social, isto é, onde o conhecimento da realidade social e política aparece como possível ou, melhor ainda, como necessário. E é nesta necessidade de uma nova ciência do político que a teoria política do século XIX acaba por juntar aquilo que seriam as análises de realidade, suas críticas, as proposiçðes de transformações, à obrigatoriedade da ação. Os ,pontos de partida podem se opor, ou indo da idéia à ação, ou partindo do pressuposto de que as ações é que dão nascimento às idéias, ou afirmando, simplesmente, que ambas fazem parte da mesma realidade; mas nenhum pensamento político do século XIX escapa a esta imbricação necessária entre teoria e prática.

(14) Cf. nota 6, p. 111 
O nascimento da ciência social acaba por reunir também o político ao social e ao econômico, levando a teoria política a uma aparente perda de autonomia. Após a confusão estabelecida por Locke, ao colocar a questão da Liberdade e da Igualdade ao lado da questão da Propriedade, embora sua conotação de propriedade fosse mais ampla, ${ }^{14}$ a propriedade, com sua conotação econômica, vincula-se definitivamente à questão fundamental da Ciência Política. Torna-se assim difícil, para toda e qualquer Teoria Política, ignorar a questão da Propriedade, da riqueza, do status, enfim, do fator econômico e social, ao tratar do tema da Igualdade e da Liberdade.

Os pensadores políticos do século XIX, ao juntarem às suas idéias o imperativo da ação, iniciam uma discussão que permanece viva, até hoje, em todo o campo da ciência política. O fato de que o conhecimento da realidade é algo absolutamente obrigatório para se adquirir a consciência do fenômeno político e poder agir corretamente, leva à idéia moderna da ligação essencial entre teoria e prática. É como se o texto bíblico - "a fé sem obras é morta" - perdesse sua conotação religiosa para assumir uma conotação científica. Na verdade, não apenas se abandona o domínio das idéias abstratas, mas também se exige que a prática tenha justificação teórica. ${ }^{15}$

O Liberalismo Político do século XIX não escapa a todas essas preocupaçōes. Suas análises, proposições e soluções, sem abandonarem a questão da Igualdade e da Liberdade, abordam necessariamente esses novos temas. Este pensamento político liberal pós-revoluções não será apenas crítico do liberal clássico, embora seja seu herdeiro mais direto, mas terá sempre presentes, também, os acontecimentos revolucionários de 89 e as soluçôes concretas dadas pelas Revoluções Inglesa e Americana. Está ainda mais próximo destas duas últimas, talvez por serem mais liberais que a francesa, ao determinarem várias saídas constitucionais e institucionais liberais para a preservação da Liberdade e o estabelecimento da Igualdade.

A crítica deste novo liberalismo ao pensamento político clássico será dirigida, sobretudo, à idéia dos Direitos Naturais dos Homens, à verificação de que estes apareciam como abstrações anárquicas (como na Revolução Francesa, onde mesmo a Vontade Geral rousseauniana é tão mal compreendida). Tentar-se-á defini-los, localizando-os no espaço e encontrando algo que os garanta na realidade. Assim é que logo será abandonada a expressão "Direitos Naturais dos Homens", na sua univer-

(15) O pensamento político clássico, na verđade, já havia, com Maquiavel, levantado esta questão. Em $O$ Príncipe é uma constante o ensinamento de que é necessário o conhecimento da realidade, do seu povo, para que a ação do Príncipe tenha eficácia. 
salidade - que a Revolução Francesa e as guerras napoleônicas ajudaram a espalhar -, para transformar-se em "Direito dos Franceses", "Direito dos Ingleses", etc.

Para os novos liberais, as Revoluções Inglesa e Americana poderiam ser encaradas como pontos de partida para o estabelecimento de regimes liberais, onde alguns de seus mais caros valores já estavam presentes; a Revolução Francesa, por vezes, no entanto, aparecia-lhes como uma grande tragédia. Tragédia esta devida, sobretudo, à desesperada tentativa dos revolucionários, em particular dos jacobinos, de estabelecer a Igualdade em detrimento da Liberdade. Era como se as Revoluções Inglesa e Americana apenas tivessem implantado a Liberdade para aqueles que já eram de alguma forma iguais, enquanto a Francesa havia tentado realizar Liberdade e Igualdade ao mesmo tempo. E é a partir do drama desta contradição fundamental - Liberdade-Igualdade - que o novo Liberalismo se volta contra aqueles que haviam estabelecido que a Liberdade e a Igualdade deveriam caminhar juntas.

$\mathrm{O}$ medo de Revoluções que novamente colocassem lado a lado as duas reivindicações, trazendo consigo a necessidade da violência, como a de 89 , faz com que os novos Liberais sejam, acima de tudo, anti-revolucionários. ${ }^{16}$

Este temor da Revolução está intimamente ligado a um pavor maior: o de uma Igualdade que se tentasse estabelecer "aqui e agora". Não é apenas o terror à desordem, mas, muito mais, o medo da destruição do Indivíduo, das liberdades individuais. Nada pior, para um Liberal do século XIX, do que a submissão do Indivíduo, de suas vontades particulares, enquanto privadas, à Sociedade ou ao Estado.

Nesta defesa do Indivíduo e de suas Liberdades, o novo Liberalismo acaba por estabelecer uma separação bastante nítida entre o público e o privado. Tenta ainda alargar ao máximo a esfera do privado, insistindo que só o Indivíduo é o limite para suas decisø̄es particulares. A proteção do Indivíduo é, pois, não apenas contra o Estado, mas também contra a Sociedade, em suas mais variadas manifestaçð̄es: opinião pública, preconceitos, crenças, etc.

É por tudo isto que a Igualdade pode ser ameaçadora. Por um lado, pode destruir as individualidades, obrigando os homens a se comportar segundo padrðes estabelecidos socialmente; por outro, há sempre a ameaça da tirania de um Estado, legitimado por uma massa de iguais, onde minorias dissidentes não encontrassesm espaço político para se XIX é cheio de revoltas e revoluçōes lideradas por Liberais que defendiam justa-
mente os princípios do novo liberalismo. 
manifestar. $^{17}$

Assim, este novo Liberalismo se volta, ao mesmo tempo, contra a Sociedade e o Estado, mas sabe também que não pode passar sem eles. O seu trabalho será constantemente o de buscar os limites necessários de uma ou outra dominação. Enfim, até que ponto Sociedade e Estado irão perturbar as liberdades fundamentais do Individuo? Melhor explicando: se Sociedade e Estado existem e são necessários, para evitar a desordem e a anarquia, suas funçб̄es e poderes devem ser limitados, de tal forma que a massa e a maioria não sejam impositivas e o poder do Estado não destrua o Indivíduo e suas criaçôes. A favor do Estado e da Sociedade, mas apenas como garantia da Liberdade do Indivíduo, e como proteção contra os "outros".

Eis por que Liberdade e Igualdade são vistas como contraditórias. Mas, embora contraditórias no presente, elas não sã muito pelo contrário, constituem a meta a ser atingida num futuro, quando o desenvolvimento tecnológico, a educação e a riqueza tiverem transformado gradativamente e pacificamente os indivíduos em homens mais iguais, sem sacrifício da Liberdade. Se a Democracia, considerada como a Sociedade de iguais, pode ser algo que atente para a Liberdade dos Indivíduos, na medida em que esta Igualdade pressuponha uma massa tirânica, esta tirania poderá ser evitada se a Igualdade for a dos cidadãos. Portanto, sem abandonar, nem um minuto sequer, a defesa da Liberdade, a Igualdade assume o caráter de um vir-a-ser, na medida em que a cidadania pode ser conquistada. É esta conquista da cidadania que passa a ser a meta dos novos Liberais para a solução da contradição entre a Liberdade e a Igualdade.

A tal ponto esta conquista da cidadania é o fulcro deste neo-

(17) Esta defesa do Individualismo era uma constante nos escritos e discursos liberais do século XIX. Veja-se, por exemplo, como Benjamin Constant defende a liberdade individual face à soberania dos cidadãos: "A universalidade dos cidadãos é o soberano, isto é, nenhum indivíduo, nenhuma facção, nenhuma associação parcial pode se arrogar o direito à soberania, se ela não the foi delegada. Mas a partir desta constatação não se pode inferir que a universalidade dos cidadãos, ou aqueles que por ela são investidos da soberania, possam dispor soberanamente da existência dos indivíduos. Há, ao contrário, uma parte da existência humana que, necessariamente, permanece individual e independente, e que de direito está fora de toda competência social. A soberania só existe de uma maneira limitada e relativa. A jurisdição desta soberania acaba onde começa a independência e a existência individual... a sociedade não pode exceder sua competência sem ser usurpadora, a maioria, sem ser facciosa" (CONSTANT, B. - Cours de Politique Constitutionnelle, Paris, Librairie de Guillaumin, 1861, p. 9). Ou então Stuart Mill: "O princípio de todas as coisas sábias ou nobres vem e deve vir dos indivíduos", ou ainda: "Ao indivíduo deve pertencer a parte da vida na qual é o principal interessado" (Mill, J. S. - On Liberty, Oxford, B. Blackwell, 1948, p. 59). 
Liberalismo, que muitas vezes confunde-se com a conquista da Felicidade, que não $C$ inteiramente alheia à conquista do Bem-Estar e da Propriedade. ${ }^{18}$

É verdade que, nesta conquista da cidadania e, portanto, da Felicidade e do Bem-Estar, há sempre uma enorme ambigüidade implícita nas preocupações liberais do século XIX. Ao mesmo tempo que o Progresso é inevitável, e mesmo necessário, para se atingir a Liberdade, a Igualdade e o Bem-Estar, ele pode também ser destruidor da própria Liberdade. Pois este mesmo Progresso introduz novos valores, como o da riqueza e o da propriedade, para se atingir o Bem-Estar, transformando os homens em seus escravos, ameaçando justamente a criatividade livre que só a Liberdade individual pode permitir. Eis por que, também, um forte Romantismo impregnará tal ambigüidade. São os velhos valores do Antigo Regime, aliados a um temor ao desenvolvimento industrial, que irão se opor à destruição das pequenas comunidades e sua transformação em grandes concentrações urbanas e massificantes.

É como se o Progresso, ao mesmo tempo que libera e torna mais homens iguais, pudesse também transformá-los em escravos da produção e do consumo, criando uma outra desigualdade, pior ainda que a

Mas, se o reino da Igualdade e da Liberdade e, portanto, a Felicidade dos Indivíduos, da Nação e mesmo da Humanidade, está no futuro, é preciso organizar o caminhar para lá, para que novas revoluçð̄es não sejam necessárias e que tudo possa ser atingido pacificamente, o que significa, para os Liberais, legalmente, isto é, dentro da ordem constitucional. Assim, a Lei, as Constituições e sua respeitabilidade serão elementos fundamentais que garantirão a Igualdade e a Liberdade. A impressão que se tem é que os Liberais do século XIX tomam de Rousseau a idéia de que a Lei é a expressão da Vontade Geral (não importa se não o é) e a colocam no Poder Legislativo de Locke, com toda sua legitimidade dada pelo voto da maioria. São, portanto, as Constituiçốes,

(18) $\hat{E}$ interessante notar que a Declaração da Independência Americana, em 1776, havia já substituído a trilogia lockeana - Liberdade, Igualdade, Propriedade - por Vida-Liberdade-Busca da Felicidade. Já a Revolução de 89, na sua Declaração dos Direitos do Homem e do Cidadão, além, evidentemente, de estabelecer que os "homens nascem livres e iguais", declara que os seus Direitos Naturais são "a Liberdade e a Propriedade". Nesta perspectiva e no seu horror a 89 , sem dúvida os liberais do século XIX, mesmo os franceses, sentir-se-ão sempre mais próximos do Bill of Rights do que da Declaração de 89.

(19) $\hat{E}$ interessante notar também que a idéia de Democracia, como a de uma organização social e política de iguais, vai se chocar com os ideais liberais. Há, continuamente, um esforço para juntá-los em Democracias Liberais, a tal ponto que acabam por erroneamente se confundir. Pois, para os Liberais do século XIX, a Democracia é uma meta a ser atingida num processo de igualização. 
como Lei suprema, que irão estabelecer que "todos os homens são iguais perante a Lei", e igualmente definir tanto os limites entre o Direito Público e o Privado quanto o possível controle do poder do Estado, para que a Liberdade Individual possa ser preservada da opressão da Sociedade e do poder do Estado.

A questão da Liberdade e da Igualdade é, desta forma, resolvida pelas Constituições Liberais, na medida em que declaram que os Cidadãos são iguais e livres. Não podemos nos esquecer, entretanto, como já dissemos, que a cidadania não é para todos: ela é algo a ser conquistado, de preferência lentamente, mas sempre dentro da Lei.

Estamos retomando, sem dúvida, a nossa questão inicial e fundamental para todo o pensamento político: Liberdade para que e para quem?

O novo Liberalismo não terá nenhum pudor em estabelecer quem são os Cidadãos. Mas não será também sem polêmica que cada Nação decidirá por onde passar o corte da cidadania.

De imediato, é óbvio que o escravo não é Cidadão. A questão que se coloca é outra: deve o escravo ser libertado para que assim possa alcançar a cidadania? Embora a Nação Americana continuasse a ter escravos, é verdade que a maioria das naçōes européias já não os possuía, mas o debate continuará acirrado em tomo da extinção ou não da escravidão nas colônias. ${ }^{20}$

Mas, se pode parecer mais ou menos óbvio que o escravo não pode ser Cidadão, os demais cortes da cidadania não são necessariamente tão evidentes. Eis por que a gama desta escolha pode ser a mais variada. Duas únicas condições serão aceitas universalmente: a da nacionalidade e a do sexo. Todas as demais qualificaçōes variarão, não apenas na cabeça dos Liberais, mas também nas várias Constituiçōes Liberais Nacionais. Em geral, acentua-se o fato de que este corte da cidadania passa quase sempre pela riqueza e pela propriedade, mas ele também se faz comumente pela idade ou pela educação.

O Liberalismo político do século XIX aceita tranqüilamente a fórmula, já expressa, de que a Liberdade e os Direitos Políticos serão privilégios dos Cidadãos, e não de todos os habitantes da Nação.

Resolve-se, assim, a questão da Liberdade e da Igualdade, pela simples formulação de que os "Cidadãos são livres e Iguais" e pela restrição temporária da cidadania.

Mas, se a cidadania pode ser uma conquista, repetimos, esta deverá

(20) Em torno dessa discussão, talvez o caso mais exemplar seja o de Thomas Jefferson, que, apesar de ser a favor da libertação dos escravos, acaba por aceitar que a Constituição Americana mantenha a escravidão, continuando, ele mesmo, a guardar os seus escravos. Tocqueville irá defender no Congresso a libertação dos escravos nas Colônias Francesas. 
ser feita pacificamente e dentro da Lei. Nesta perspectiva, este Liberalismo irá acentuar a necessidade de que os caminhos escolhidos não perturbem a Liberdade. Há realmente um reconhecimento de que, se a Liberdade é para poucos agora, somente a sua preservação poderá permitir que algum dia ela seja para todos. É com esta preocupação fundamental que os novos Liberais traçam os caminhos para a obtenção da cidadania e estabelecem alguns princípios essenciais. Estes, confundidos por vezes, procuram garantir que, ao se expandir a Igualdade, não se destrua nem violente a Liberdade para que assim, permanecendo integra, possa igualmente, no futuro, ser para todos.

Estas soluçð̃es serão muito claras. Em primeiro lugar, apesar do necessário Progresso da Sociedade e da existência do Estado, sempre serão a favor do Cidadão. Em segundo lugar, formalmente, as Constituiçб̃es estabelecerão quais são as Liberdades e quem são os iguais legalmente. Mas, e este talvez seja o aspecto mais interessante do Liberalismo do século XIX, a garantia de que esta Liberdade e esta Igualdade não serão apenas formais dependerá necessariamente das próprias criações e açōes dos Cidadãos.

Os caminhos seguros e os princípios fundamentais para a salvaguarda da Liberdade são traçados e enunciados pelos cidadãos. Alguns, como as Instituiçбes livres, a descentralização administrativa do Estado, a educação livre, a liberdade individual, são já reconhecidos como elementos essenciais para a garantia da Liberdade. Mas, o que se reconhece, também, é que é a ação política constante dos cidadãos que irá permitir a constituição e a manutenção de sua Liberdade.

É esta ação política constante que possibilitará a existência de manifestaçס̄es livres de todos, mesmo daqueles que ainda não são Cidadãos, permitindo assim o alargamento da cidadania. As transformaçðes sociais e políticas, as reformas possiveis são assim conquistadas, como se tudo apenas fosse um longo e constante aprendizado para o gozo da Liberdade. E, quando todos tivessem tudo aprendido, só então a Liberdade e a Igualdade não mais seriam contraditórias. ${ }^{21}$

É nesta ênfase na ação política, como garantia da Liberdade, que Alexis de Tocqueville provavelmente dá a sua maior contribuição ao novo pensamento Liberal, que começa a se delinear na primeira metade do século XIX. Sem dúvida, esta necessidade de participação, para que não se destrua a Liberdade, já havia sido levantada na Revolução Americana, mas Tocqueville é o primeiro a mostrar a sua importância, explicando-a; aliás, tomando como objeto de sua explicação a própria Democracia Americana. É, também, porque está preocupado com o problema da Liberdade que vai tentar entender o que é Demo-

(21) Da mesma forma a Democracia e o Liberalismo deixariam de ser contraditórios. 
cracia. E é ainda por compreender que a Democracia é um processo de igualização crescente, inevitável, e ameaçador da Liberdade, que vai expor os caminhos e os princípios liberais de salvaguarda a serem seguidos.

Falamos até aqui de um Liberalismo genérico, quando, talvez, devêssemos especificar as diferenças entre o inglês, o francês, o italiano, etc., já que mesmo a palavra "Liberal" não significava a mesma coisa em cada país. ${ }^{22}$

O Liberalismo Nacionalista é realmente um fato, e, na grande maioria das vezes, é mais romântico e aparece mais identificado com o povo do que com a Nação. ${ }^{23}$

Mas, se cada Nação desenvolve o seu Liberalismo, a impressão que temos é que o pensamento liberal do século XIX é tipicamente inglês. A tal ponto isto parece verdadeiro que a maioria dos liberais franceses tem necessariamente alguma ligação com a Inglaterra ou com o mundo inglês. Sem falarmos no fato de que as Instituiçōes Políticas inglesas são sempre o grande exemplo a ser seguido, os liberais franceses ou passam longas temporadas na Inglaterra, estudando-a para me-

(22) O termo "Liberal", significando um tipo de opinião política, era novo no século XIX. Foi primeiramente usado para designar na Espanha os rebeldes de 1820 . Na Inglaterra, por volta de 1820 , era conhecido na sua forma francesa ou espanhola: falava-se em "English Libéraux" ou "English Liberales", com uma certa conotação pejorativa. $\hat{E}$ somente em meados do século que o termo assume uma significação respeitável. Mas, pelos anos 60 , Liberais na Inglaterra são os membros do partido de Gladstone. Muitas outras significações são encontradas durante o século XIX para o termo, segundo as diferentes lutas políticas de cada região. Na França, é primeiramente difundido pelos "realistas" para designar, durante a Restauração, seus oponentes à esquerda na Câmara. A denominação de Liberal continua a ser usada confusamente na França por muito tempo, a tal ponto que tanto Thiers quanto Barrot ou Guizot foram denominados Liberais.

(23) É interessante notar, por exemplo, como Louis Philippe se autodenominava "Rei dos Franceses" e não "Rei da França". Poderíamos também observar como, por todo o século XIX, há, nas Letras e nas Artes em geral, expressōes que não são necessariamente contraditórias, estabelecendo relaçôes entre um caráter nacional, racional e grandioso, de um lado, e um popular, romântico e gracioso, de outro. Poderíamos citar, por exemplo: Chopin ou Lizst, mais próximos do popular romântico, em contraposição a um Wagner, mais perto do nacional grandioso. Da mesma forma, nas artes plásticas, um movimento como o dos PréRafaelistas na Inglaterra comparado com um David na França; ou ainda, na literatura, Walter Scott e um Balzac. 
lhor compreender sua organização política, ou, muitas vezes, têm laços mais profundos como os religiosos ou afetivos. ${ }^{24}$

(24) Já Montesquieu e Voltaire haviam sofrido, como demonstram suas obras, uma enorme influência do mundo inglês, mais liberal (após as revoluções do século XVII) que o francês. Mas é interessante como os liberais franceses, no século XIX, quase sempre estão intimamente ligados à Inglaterra, não só através do mundo político, mas também por laços pessoais. Curiosamente, Benjamin Constant e Mme. de Staël, por exemplo, além de serem protestantes, passam longas temporadas na Inglaterra. Tocqueville não só desenvolve suas idéias liberais a partir da Democracia Americana, mas também das Instituições políticas inglesas que admira. É mais curioso ainda o fato de que tanto ele como o poeta Lamartine (também considerado um liberal) casam-se com inglesas protestantes. 